\title{
Chemical diffusion of fluorine in jadeite melt at high pressure
}

\author{
DONALD B. Dingwell and CHRISTOPHER M. SCARFE \\ Experimental Petrology Laboratory, Department of Geology, University of Alberta, Edmonton, Alberta T6G 2E3
}

(Received March 27, 1984; accepted in revised form September 4, 1984)

\begin{abstract}
The chemical diffusion of fluorine in jadeite melt has been investigated from 10 to 15 kbars and 1200 to $1400^{\circ} \mathrm{C}$ using diffusion couples of jadeite melt and fluorine-bearing jadeite melt $(6.3 \mathrm{wt} . \% \mathrm{~F})$. The diffusion profile data indicate that the diffusion process is concentration-independent, binary, F-O interdiffusion. The F-O interdiffusion coefficient ranges from $1.3 \times 10^{-7}$ to $7.1 \times 10^{-7} \mathrm{~cm}^{2} /$ sec and is much larger than those obtained by KusHIRo (1983) for Si-Ge and Al-Ga interdiffusion in jadeitic melts. The Arrhenius activation energy of diffusion is in the range of 36 to $39 \mathrm{kcal} / \mathrm{mole}$ as compared with $19 \mathrm{kcal} / \mathrm{mole}$ for fluorine tracer diffusion in a lime-aluminosilicate melt. The diffusivity and activation energy of $\mathrm{F}-\mathrm{O}$ interdiffusion vary slightly with pressure, but the pressure dependence of $\mathrm{F}$ $\mathrm{O}, \mathrm{Al}-\mathrm{Ga}$ and $\mathrm{Si}-\mathrm{Ge}$ interdiffusion may be related to the relative volumes of the interdiffusing species for each pair. The magnitude of chemical diffusivity of fluorine is comparable to that of the chemical diffusivity of water in obsidian melts. The diffusivities of various cations are significantly increased by the addition of fluorine or water to a silicate melt. This fact, combined with the high diffusivity of fluorine, suggests that the $F$ ion is the principal diffusing species in dry aluminosilicate melts and that dissolved fluorine will accelerate chemical equilibration in dry igneous melts.
\end{abstract}

\section{INTRODUCTION}

A KNOWLEDGE of the transport properties of melts of geologic interest is required in order to model their behavior during petrogenetic processes. In particular, cationic and anionic diffusivities in silicate melts allow us to relate time, temperature, and physical scale in processes where diffusion is the ratelimiting step. Examples of such igneous processes include both melt-vapour and melt-crystal interactions (e.g. growth of zoned minerals, vapour phase transport of dissolved metals during magma degassing, crustal assimilation) and intra-melt processes such as thermogravitational diffusion and double-diffusive convection.

Fluorine, like water, has a considerable effect on many properties of silicate melts including viscosities (DINGWELl et al., 1984), phase equilibria (MANNING et al., 1980), melt-vapour partitioning (HARDS, 1978), and, as discussed below, component diffusivities in the melt. The occurrence of fluorine-rich amphiboles and micas in the lower crust and upper mantle (SMITH et al., 1981; VALLEY et al., 1982) and the suggestion that many relatively dry, fluorine-rich, melts originate from these regions (HARRIS and MARRINER, 1980; BURT et al., 1982) indicate the need for a better understanding of the role of fluorine in melts at high pressures. Such considerations, along with the potential for insights into the structure of $F$ and $\mathrm{H}_{2} \mathrm{O}$-bearing melts, prompted this study. Jadeite melt was chosen for this study because it has been used as a model for polymerized silicate melts in several studies (e.g. melt viscosity, KUSHIRO, 1976; oxygen diffusivity, SHIMIZU and KUSHIRO, 1984; cationic diffusivities, KUSHIRO, 1983; Raman spectra, SHARMA et al., 1979, SEIFERT et al., 1982; fluorinebearing melt viscosity, DinGwell et al., 1984).

\section{EXPERIMENTAL METHOD}

The starting materials were (1) fluorine-bearing jadeite glass prepared from reagent-grade sodium carbonate, alumina, aluminum fluoride and purified quartz sand and (2) jadeite glass prepared from a gel, dehydrated at $800^{\circ} \mathrm{C}$ for two hours. These starting glasses were analysed for $\mathrm{Na}, \mathrm{Al}$ and Si by energy dispersive analysis using an ARL SEMQ microprobe fitted with an EEDS-ORTEC energy dispersive spectrometer. Operating conditions were $15 \mathrm{kV}$ accelerating voltage, $4 \mathrm{nA}$ sample current and $240 \mathrm{sec}$ counting time. The fluorine content of the fluorine-bearing starting glass was determined by neutron activation analysis as described in DINGWELL et al. (1984). Analyses of the starting glasses are presented in Table 1.

The diffusion couple technique of KUSHIRo (1983) was used for this study. Glasses were ground in an agate mortar and packed into ( $5 \mathrm{~mm}$ diameter by $8-10 \mathrm{~mm}$ length) platinum capsules using a tight-fitting, stainless steel tool. The denser, fluorine-free powder was packed into the capsule first and occupied the lower end of the vertical diffusion couple in all experiments. Packed and crimped capsules were dried at $800^{\circ} \mathrm{C}$ for 10 minutes and immediately welded. Sealed capsules were packed with hematite powder into $3 / 4$ inch furnace assemblies with tapered graphite heaters, which reduce the temperature gradient along the $10 \mathrm{~mm}$ capsule to $15^{\circ} \mathrm{C}$ (KusHro, 1976). The hematite acts as a trap for any water diffusing into the charge from the assembly. The assemblies were stored in a drying oven at $110^{\circ} \mathrm{C}$ prior to use.

Temperatures were monitored with a $\mathrm{Pt} / \mathrm{Pt13Rh}$ thermocouple without any correction for pressure, and are believed accurate to better than $\pm 10^{\circ} \mathrm{C}$. Pressures were monitored continuously with a Bourdon-tube gauge and were accurate to within \pm 0.5 kbars. Pressure calibrations were performed using the melting curve of $\mathrm{NaCl}$ (CLARK, 1959 ) and a pressure correction of $-7 \%$ was applied to all runs.

Run durations were one hour with the exception of a zero-time experiment and one $1 / 2$ hour experiment (run numbers 12 and 10 , respectively). The zero-time experiment provided confirmation of an initially flat interface. Runs were quenched by switching off the power to the heater resulting in quench rates of approximately $125^{\circ} \mathrm{C} / \mathrm{sec}$. Quenched runs (encased in coarsely recrystallized specular 
Table 1. Analyses of starting glasses*

\begin{tabular}{cccc} 
Element & Jadeite & $\begin{array}{c}\text { Fluorine } \\
\text { bearing } \\
\text { Jadeite }\end{array}$ & $\begin{array}{c}\text { Stoichio- } \\
\text { metric } \\
\text { Jadeite }\end{array}$ \\
\hline $\mathrm{Na}$ & 11.15 & 11.17 & 11.33 \\
$\mathrm{~A} 1$ & 13.34 & 12.75 & 13.34 \\
$\mathrm{Si}$ & 27.92 & 26.72 & 27.79 \\
0 & 47.56 & 43.00 & 47.54 \\
$\mathrm{~F}$ & - & 6.3 & - \\
TOTAL & 99.97 & 99.94 & 100.00
\end{tabular}

* Na, AT and Si detemined by electron microprabe; $F$ determined by neutron activation analysis; 0 by stolchiometry. Errors for microprobe data expressed as percent of the amount present at 3 standard deviations: $\mathrm{Na}(4.3 \%), \mathrm{Al}(2.0 \%), 5 i(1.0 \%)$. Errors in fluorine analysis are +0.1 wtz $F$ at 1 standard deviation.

hematite) were set in epoxy and sliced in half longitudinally. The platinum capsules preserved their cylindrical form with only minor necking during the run. Thin sections of the charges were examined optically revealing colorless, transparent glasses with no crystals (even for one run conducted below the liquidus of jadeite at $1200^{\circ} \mathrm{C}$ and $\left.15 \mathrm{kbars}\right)$. The melt couple interfaces were optically invisible.

The charges were analysed after each experiment for $\mathrm{Na}$. $\mathrm{Al}$ and $\mathrm{Si}$ by the energy dispersive technique described above and for fluorine by wavelength dispersive analysis. Fluorine analyses were standardized to a sample of the original fluorine-bearing jadeite glass. This glass had been analysed against NBS opal glass SRM \#91 by neutron activation analysis (DINGWELl et al., 1984). The use of a fluorine standard with the same matrix composition as the analysed samples minimizes errors associated with poor ZAF correction factors for fluorine.

Wavelength dispersive analysis for fluorine required a sample current of $40 \mathrm{nA}$ to achieve reasonable count rates (approximately $40 \mathrm{cps} / \mathrm{wt} \% \mathrm{~F}$ ). Therefore, in order to avoid significant volatilization during fluorine analysis two techniques were employed. In the first case, a point beam was moved continuously, perpendicular to the profile, covering a distance of 50 micrometers in 100 seconds. In the second case, the beam was rastered over a $10 \times 10$ micrometer area for 100 seconds. The fluorine totals normalized to the standard were identical for both techniques and chart recordings showed that no significant volatilization of fluorine occurred during the stationary analyses. Fluorine (WDA) and $\mathrm{Na}, \mathrm{Al}$ and $\mathrm{Si}$ (EDA) spectra were combined and reduced using EDATA2 (SMITH and GOLD, 1979).

\section{RESULTS}

This study involves chemical diffusion. Therefore, before the data are discussed and comparisons are made, we must distinguish between three categories of diffusion, namely, tracer, self and chemical diffusion. Self-diffusion is the diffusion of a single chemical species in the absence of a chemical gradient. This type of diffusion is usually investigated by labelling some of the diffusing atoms with an isotopic tracer (e.g. SHIMIZU and KUSHIRO, 1984). Tracer diffusion is the diffusion of an individual species at such low concentration that diffusing tracer atoms are effectively isolated from each other. The rate of diffusion will be independent of gradients. The tracer is usually a radioisotope (e.g. WATSON, 1979) and the tracer concentration is so small that no significant concentration gradients result for any of the other melt components. Chemical diffusion is the diffusion of two or more species in response to a chemical activity gradient (e.g. KuSHIRO, 1983). Tracer and self-diffusion are practically equivalent for natural melts and usually represent minimum diffusivities for the components being studied because there is no large chemical activity gradient to serve as a driving force for diffusion. The similarity of tracer and self-diffusion is evidenced by the fact that they are both described mathematically by the single component form of Fick's first and second laws (CRANK, 1975; HOFMANN. 1980). In a general sense, chemical diffusion is a multicomponent phenomenon, but it may be approximated to a binary interdiffusion process when the chemical activity gradient for all other species (and the resulting diffusion of these species) is insig nificant. For such cases, an effective binary diffusion coefficient (EBDC) may be obtained (COOPER. 1968) and we may talk in terms of a binary interdiffusion coefficient.

In the present study quantitative analyses for $\mathrm{Na}$, $\mathrm{Al}$ and $\mathrm{Si}$ revealed no concentration gradients indicating that the diffusion process could be approximated by binary interdiffusion of fluorine and oxygen. (We realize that we cannot rule out entirely the possibility of minor water-fluorine interdiffusion due to the possible presence of traces of dissolved water.) Diffusion profiles of fluorine (Fig. 1) were fitted to the following form of equation (CRANK, 1975):

$$
\frac{|x|}{2 \sqrt{D t}}=e^{\prime \prime 1}\left(\frac{2 C-\left(C_{1}+C_{2}\right)}{C_{1}-C_{2}}\right)
$$

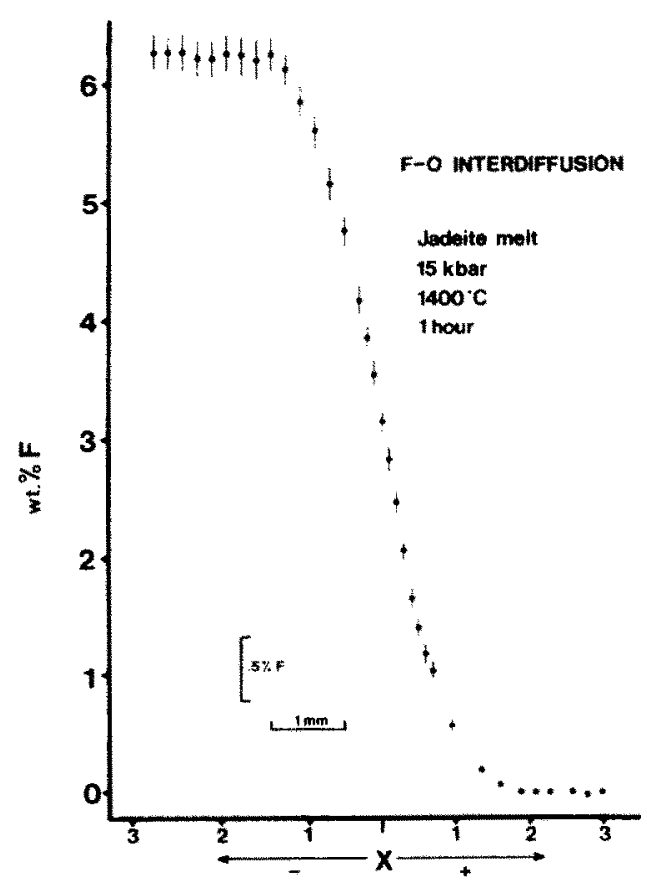

Fio. 1. Diffusion profile of fluorine in jadeite melt. 
where $D$ is the interdiffusion coefficient $\left(\mathrm{cm}^{2} / \mathrm{sec}\right), t$ is time (seconds) and $C, C_{1}$ and $C_{2}$ are the concentration at distance $x$, the maximum and the minimum concentrations of fluorine, respectively. $\operatorname{Erf}^{-1}$ is the inverse of the error function. The interface $(x=0)$ was optically invisible and, therefore, the half maximum of the diffusion profile was chosen to represent the interface. This choice was confirmed by the fit of the error function (Fig. 2). Identical diffusion profiles at several locations across each charge ruled out the possibility of significant deformation of the interface during individual runs. Plotting $\operatorname{erf}^{-1}\left(\left(2 C-\left(C_{1}\right.\right.\right.$ $\left.\left.\left.+C_{2}\right)\right) /\left(C_{1}-C_{2}\right)\right)$ vs. $x$ (Fig. 2) yields linear plots whose slopes equal $1 /(2 \sqrt{D t})$. A linear dependence of $\operatorname{erf}^{-1}\left(\left(C-\left(C_{1}+C_{2}\right)\right) /\left(C_{1}-C_{2}\right)\right)$ on $x$ indicates that the diffusion process is independent of concentration. The values of $D$ obtained from each run are presented in Table 2.

The data of Fig. 3 show increasing diffusivity of fluorine with increasing temperature. If we assume a linear dependence of $\log D$ on reciprocal temperature, we may fit the data of Table 2 to an Arrhenius equation for each pressure. The temperature dependence of diffusion is represented by the following form of equation:

$$
\log _{10} D=\log _{10} D_{0}-E a / 2.303 R T
$$

where $D$ is the diffusion coefficient at temperature $T$ (K), $D_{0}$ is the Arrhenius frequency factor, $R$ is the gas constant and $E a$ is termed the Arrhenian activa-

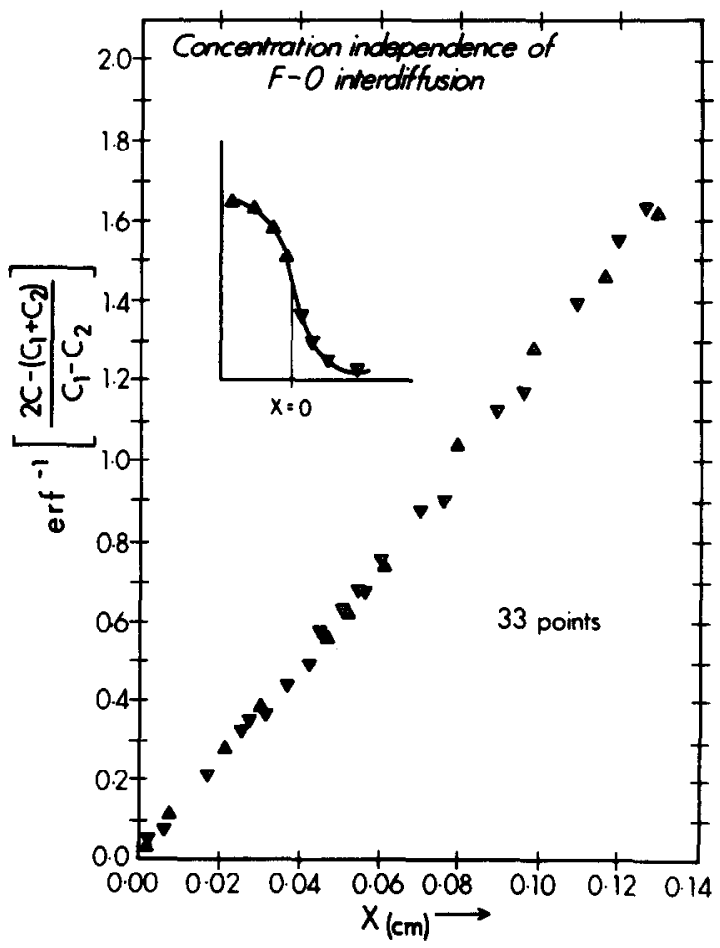

FIG. 2. Reduced diffusion profile using Eqn. (1) and data from F-rich (triangles) and F-poor (inverted triangles) limbs of the diffusion profile. The slope corresponds to $1 /(2 \sqrt{D t})$ (Data from run no. 3).
Table 2. Experimental conditions and results

\begin{tabular}{lccccc}
\hline Run & $\begin{array}{c}\text { Temperature } \\
\left({ }^{\circ} \mathrm{C}\right)\end{array}$ & $\begin{array}{c}\text { Pressure } \\
(\text { kbars })\end{array}$ & $\begin{array}{c}\text { Duration } \\
(\mathrm{sec})\end{array}$ & $\begin{array}{l}\text { log } \mathrm{D}_{\mathrm{T}} \\
\left(\mathrm{cm}^{2} / \mathrm{sec}\right)\end{array}$ & * of points \\
\hline 1 & 1400 & 15 & 3600 & $-6.18 \pm .04$ & 16 \\
2 & 1200 & 15 & 3600 & $-6.87 \pm .03$ & 25 \\
3 & 1300 & 15 & 3600 & $-6.39 \pm .01$ & 33 \\
4 & 1400 & 10 & 3600 & $-6.15 \pm .03$ & 20 \\
5 & 1200 & 10 & 3600 & $-6.87 \pm .02$ & 14 \\
6 & 1300 & 10 & 3600 & $-6.49 \pm .02$ & 18 \\
7 & 1300 & 12.5 & 3600 & $-6.60 \pm .04$ & 17 \\
8 & 1400 & 12.5 & 3600 & $-6.18 \pm .01$ & 9 \\
9 & 1200 & 12.5 & 3600 & $-6.87 \pm .05$ & 9 \\
10 & 1300 & 10 & 1800 & $-6.41 \pm .06$ & 11 \\
11 & 1400 & 10 & 3600 & $-6.27 \pm .02$ & 11 \\
12 & 1300 & 10 & 0 & - & -10 \\
13 & 1300 & 15 & 3600 & $-6.62 \pm .03$ & 10 \\
\hline
\end{tabular}

uncertainties in $\log D$ are quoted at 1 standard deviation.

tion energy of diffusion. The results of least squares fits to the data in Table 2 are presented in Table 3. $\mathrm{F}-\mathrm{O}$ interdiffusion activation energy is in the range of 36 to $39 \mathrm{kcal} / \mathrm{mole}$.

The pressure dependence of diffusion may be linearly approximated by an Arrhenius equation of the form:

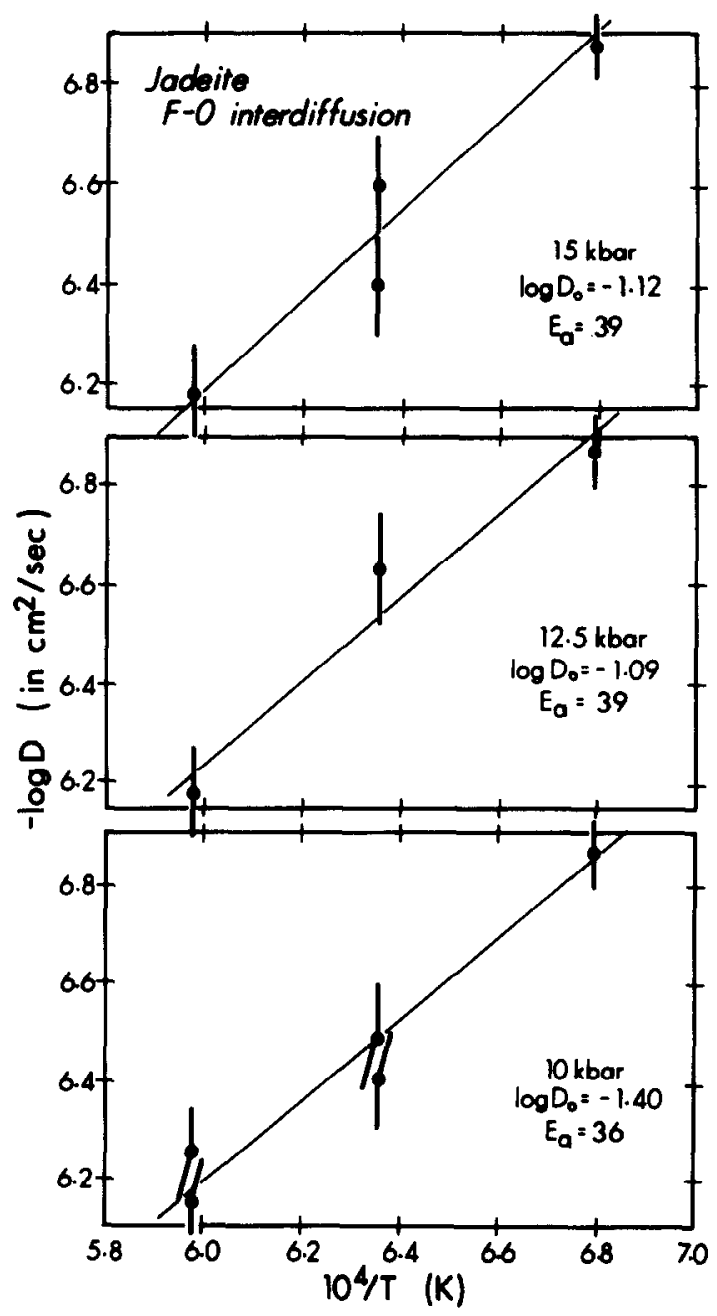

FIG. 3. Diffusion data for $10,12.5$ and 15 kbars and computed Arrhenius parameters. 
Table 3. Arrhenius parameters

\begin{tabular}{|c|c|c|c|}
\hline $\begin{array}{l}\text { Pressure } \\
\text { (kbars) }\end{array}$ & $\begin{array}{c}\text { Ea } \\
(\mathrm{kcal} / \mathrm{mole})\end{array}$ & $\log 0_{0}$ & * of points \\
\hline $\begin{array}{l}10 \\
12.5 \\
15\end{array}$ & $\begin{array}{l}36 \pm 2 \\
39 \pm 2 \\
39 \pm 4\end{array}$ & $\begin{array}{l}-1.46 \pm .3 \\
-1.18 \pm .2 \\
-1.12 \pm .6\end{array}$ & $\begin{array}{l}5 \\
3 \\
4\end{array}$ \\
\hline $\begin{array}{c}\text { Temperature } \\
\left({ }^{\circ} \mathrm{C}\right)\end{array}$ & $\left(\mathrm{cm}^{3} / \mathrm{mole}\right)$ & $\log 0_{0}$ & \# of points \\
\hline $\begin{array}{l}1200 \\
1300 \\
1400\end{array}$ & $\begin{array}{l}0.0 \\
-1.4 \pm .9 \\
0.9 \pm 1\end{array}$ & $\begin{array}{l}-6.87 \\
-6.36 \pm .09 \\
-6.27 \pm .09\end{array}$ & $\begin{array}{l}3 \\
5 \\
4\end{array}$ \\
\hline
\end{tabular}

$$
\log _{10} D=\log _{10} D_{0}-V a P / 2.303 R T
$$

where $P$ is the pressure $\left(\right.$ dyne $\left./ \mathrm{cm}^{2}\right)$ and $V a$ is the Arrhenius activation volume $\left(\mathrm{cm}^{3} /\right.$ mole). Calculated values of $\mathrm{Va}$ obtained from the least squares fits to the data for 1200,1300 and $1400^{\circ} \mathrm{C}$ are presented in Table 3 . The activation volumes are small, with large uncertainties, reflecting the extremely small pressure dependence of F-O interdiffusion. Therefore, a mean activation volume of $-0.33 \mathrm{~cm}^{2} /$ mole was calculated (based on all twelve data points) assuming temperature-independence of the activation volume.

\section{DISCUSSION}

\section{Comparison with oxygen diffusion}

SHIMIZU and KUSHIRO (1984) have measured oxygen self-diffusivity in jadeite melt from 5 to 15 kbars and 1400 to $1610^{\circ} \mathrm{C}$. They have reported self-diffusivities ranging from $6.87 \times 10^{-10}$ to $4.72 \times 10^{-10}$ $\mathrm{cm}^{2} / \mathrm{sec}$. These values are three orders of magnitude lower than the F-O interdiffusivities at the same pressure and temperature and this difference shows that the presence of anionic chemical activity gradients can result in a large increase in oxygen diffusivity. Clearly, such considerations must be taken into account when comparing the results of studies involving self diffusion (SHIMIZU and KUSHIRO, 1984) and chemical diffusion (DUNN, 1983; WENDLANDT, 1980) of oxygen.

\section{Comparison with tracer diffusion}

Tracer diffusion of fluorine has been studied by JOHNSTON et al. (1974) in a eutectic composition in $\mathrm{CaO}-\mathrm{Al}_{2} \mathrm{O}_{3}-\mathrm{SiO}_{2}$ that contains approximately $40 \mathrm{wt} \%$ $\mathrm{CaO}, 20$ wt $\% \mathrm{Al}_{2} \mathrm{O}_{3}$ and $40 \mathrm{wt} \% \mathrm{SiO}_{2}$, $\left(\mathrm{Ca}_{40} \mathrm{Al}_{20} \mathrm{Si}_{40}\right)$. The results of this study are useful for our discussion of fluorine diffusivity because $\mathrm{Ca}_{40} \mathrm{Al}_{20} \mathrm{Si}_{40}$ represents a depolymerized melt which has been well-studied in the glass literature and the diffusivities of $\mathrm{Ca}, \mathrm{Al}, \mathrm{Si}$, and $O$ have been measured. Figure 4 presents the results of tracer diffusion studies on Ca (TOWERS and ChIPMAN, 1957), Al (Henderson et al., 1961), Si
(TOWERS and CHIPMAN, 1957), and $O$ (Koros and KING, 1962; OISHI et al, 1975) in $\mathrm{Ca}_{40} \mathrm{Al}_{20} \mathrm{Si}_{40}$ melt. It is clear from Fig. 4 that fluorine diffuses faster than any of the other species in the tempcrature range studied. Also, fluorine tracer diffusivity has the lowest activation energy of any of the elements studied. As stated above, chemical diffusivities are usually larger than tracer diffusivities; however, the magnitude of tracer diffusivity in $\mathrm{Ca}_{40} \mathrm{Al}_{20} \mathrm{Si}_{40}$ melt is remarkably large. The observation that tracer diffusion in $\mathrm{Ca}_{40} \mathrm{Al}_{20} \mathrm{Si}_{40}$ melt is faster than chemical diffusion in jadeite melt implies a strong composition (and melt structure) dependence of fluorine diffusivity.

\section{Comparison with water diffusion}

Chemical diffusion of water in natural melts has been investigated by several workers (SHAW, 1974; FRIEDMAN and LONG, 1976; ARZI, 1978; JAMBON $e t$ al. 1978; DELANEY and KARSTEN, 1981; KARSTEN et al., 1982). In Fig. 5, the data for the chemical diffusion of fluorine are compared with the data available for chemical diffusion of water in obsidian melts. Although the comparison of data in Fig. 5 involves melts of jadeite and obsidian composition both represent relatively polymerized melts with alkali/aluminum molar ratios at or near $1: 1$. The comparison in Fig. 5 uses high pressure (10-15 kbars) data for fluorine and low pressure $(0.1-2$ kbars) data for water. However, the results of this study and of SHAW (1974) indicate that the pressure dependence of both fluorine and water diffusivity is small. With these provisions in mind we compare the chemical diffusivities of fluorine and water. Two aspects of this comparison are worthy of note.

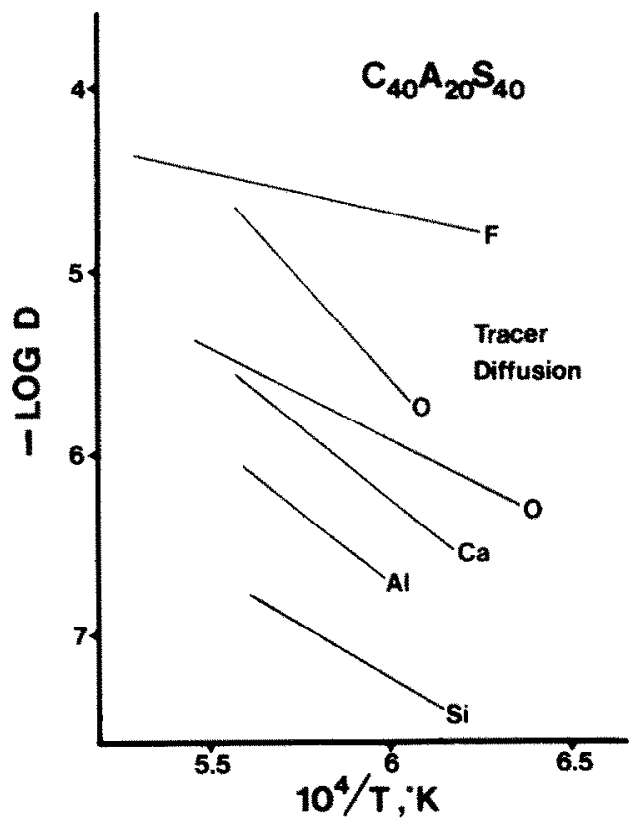

FIG. 4. Tracer diffusivities of various ions in lime-aluminosilicate meit (see text for data sources; higher oxygen diffusivity data is from Koros and KING, 1962). 


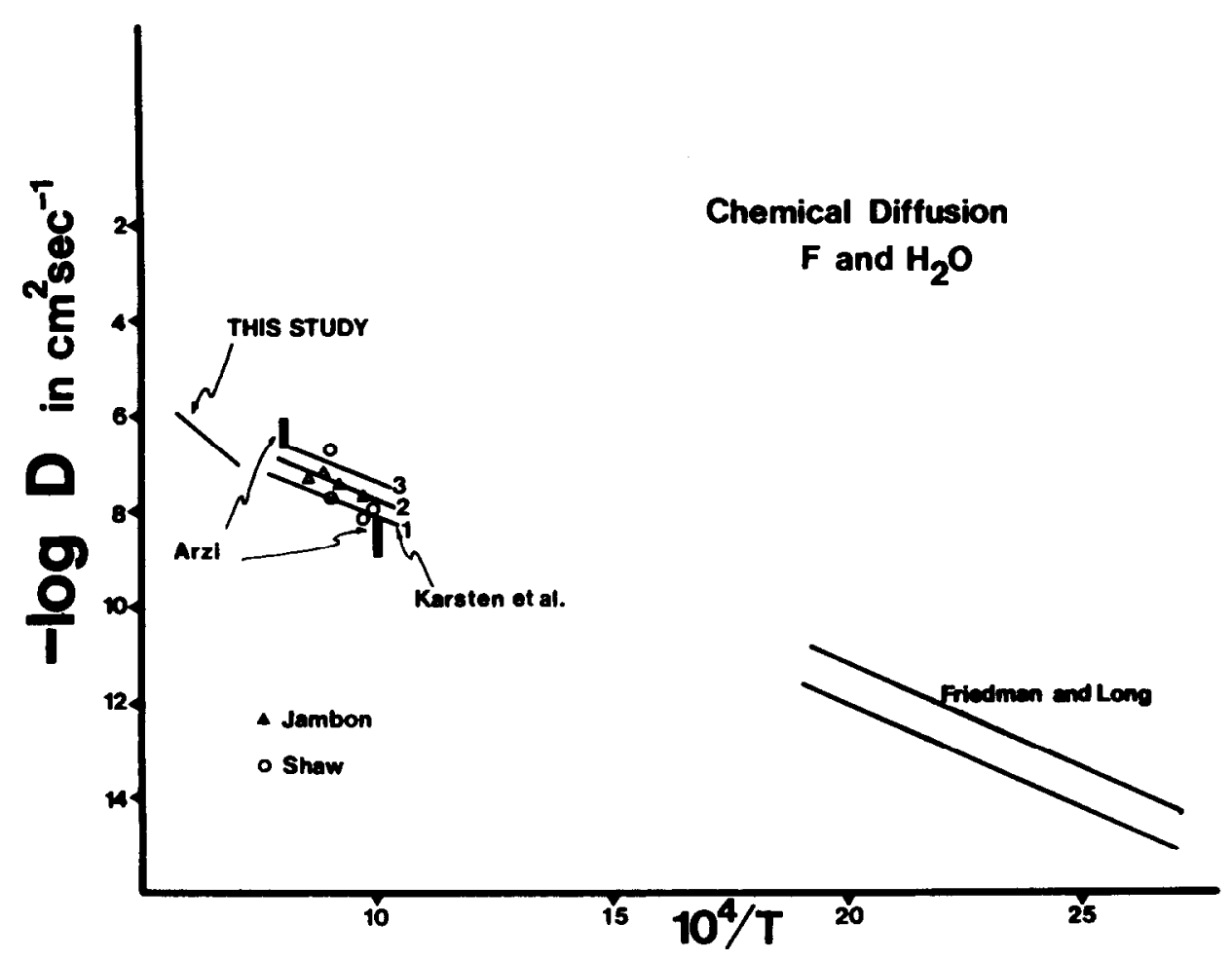

FIG. 5. Chemical diffusivities of $\mathrm{F}$ in jadeite melt and $\mathrm{H}_{2} \mathrm{O}$ in rhyolitic melts (see text for data sources).

Firstly, in the temperature range of 900 to $1400^{\circ} \mathrm{C}$ the bulk diffusivities of fluorine and water are similar. If we consider the similar size (1.21 and 1.27 angstroms, respectively, WHITTAKER and MUNTUS, 1970) and charge of $\mathrm{F}^{-}$and $\mathrm{OH}^{-}$ions, the similarity in bulk diffusivities of fluorine and water may be interpreted as indicating that the monovalent anions are the principal diffusing species. In contrast, larger diffusing species such as $\mathrm{AlF}_{6}^{3-}$ have been proposed by MANNING et al. (1980) to account for slow equilibration rates in experiments in the system haplogranite- $\mathrm{HF}-\mathrm{H}_{2} \mathrm{O}$. The diffusivity of a large complex such as $\mathrm{AlF}_{6}^{3-}$ would probably be low compared with water diffusivity. Low fluorine diffusivity was not observed in this study and, consequently, such large complexes are not considered responsible for fluorine diffusion in dry jadeite melt.

Secondly, we observe that the chemical diffusion of fluorine is independent of concentration over the range of $F /(F+O)$ (molar) $=0.0-0.11$. DELANEY and KARSTEN (1981) show significant dependence of water diffusivity on concentration over a similar concentration range. Specifically, the activation energy for chemical diffusion of water remains constant at $19 \mathrm{kcal} / \mathrm{mole}$ while the frequency factor $\left(\log _{10} \mathrm{D}_{0}\right)$ increases with water concentration. KARSTEN $e t$ al. (1982) suggest that the concentration dependence of the frequency factor results from an increasing diffusive "jump" distance with increasing water concentration and that this changing jump distance results, in turn, from the occurrence of two distinct sites for water within the melt (BURNHAM, 1979). The concentration independence of fluorine diffusivity con- trasts with this diffusive behavior of water. Thus, we must conclude that a diffusion mechanism involving only one structural site in the melt is entirely adequate to explain the concentration independence of fluorine diffusivity over the geologically relevant range of fluorine contents investigated.

\section{Comparison with Si-Ge and Al-Ga interdiffusion}

KUSHIRO (1983) has investigated Si-Ge and Al-Ga interdiffusion in jadeite melt from 6 to 20 kbars at $1400^{\circ} \mathrm{C}$. A marked assymmetry is observed in $\mathrm{Si}-\mathrm{Ge}$ and $\mathrm{Al}-\mathrm{Ga}$ interdiffusion profiles indicating a strong dependence of Si-Ge and Al-Ga interdiffusivities on $\mathrm{Si} /(\mathrm{Si}+\mathrm{Ge})$ and $\mathrm{Al} /(\mathrm{Al}+\mathrm{Ga})$, respectively (KUSHIRO, 1983). Comparison of these interdiffusion data with our data for $\mathrm{F}-\mathrm{O}$ interdiffusion at $1400^{\circ} \mathrm{C}$ and 15 kbars shows, as expected, that F-O interdiffusion is much faster than either $\mathrm{Si}-\mathrm{Ge}$ or $\mathrm{Al}-\mathrm{Ga}$ interdiffusion.

KUSHIRO (1983) did not investigate the temperature dependence of cationic interdiffusion but he showed that the pressure dependence of $\mathrm{Si}-\mathrm{Ge}$ interdiffusion was much larger than the pressure dependence of $\mathrm{Al}$ $\mathrm{Ga}$ interdiffusion. In Fig. 6, we have plotted the Arrhenius activation volume, $\mathrm{Va}\left(\mathrm{cm}^{3} / \mathrm{mole}\right)$, versus the ratio of the ionic volumes of the interdiffusing species. The ionic volumes were calculated using ionic radii from WHITTAKER and MUNTUS (1970) for $\mathrm{O}, \mathrm{F}, \mathrm{Al}, \mathrm{Si}, \mathrm{Ga}$, and $\mathrm{Ge}$. The $\mathrm{Va}$ data are least squares fits to the $1400^{\circ} \mathrm{C}$ data from KuSHIRO (1983) for Si-Ge and Al-Ga interdiffusion and the mean value of Va for F-O interdiffusion from this study. It is apparent in Fig. 6 that the relative sizes of the 


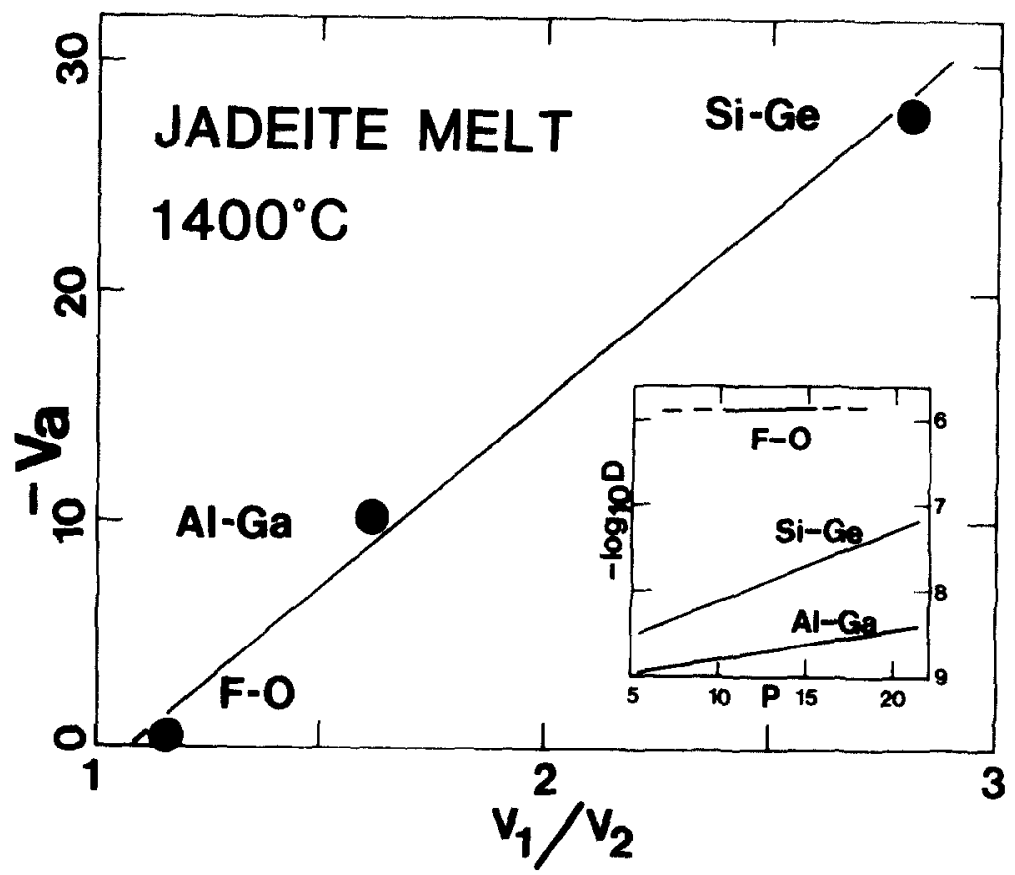

FIG. 6. Pressure dependence of F-O, Al-Ga and Si-Ge interdiffusion. Activation volume (Va) versus the ratio of ionic volumes $\left(V_{1} / V_{2}\right)$ of the interdiffusing species (symbol size corresponds to 1 standard deviation uncertainty in the $V a$ data for $\mathrm{F} . \mathrm{O}$ interdiffusion). Inset: The relative pressure dependence of $\mathrm{F}-\mathrm{O}, \mathrm{Al}-\mathrm{Ga}$ and Si-Ge interdiffusion (Al-Ga and Si-Ge data from KuSHIRO, 1983).

interdiffusing species are a large factor in determining the pressure dependence of interdiffusion. Therefore, it is anticipated that the pressure dependence of interdiffusion contains little, if any, information on the pressure dependence of self-diffusion.

\section{Compensation relationships}

Figure 7 is a plot of the frequency factor of Eqn. (2) versus the activation encrgy of diffusion. We will use Fig. 7 for two purposes. Firstly, we will discuss the correlation between frequency factors and activation energies (i.e. compensation) and secondly, we will use Fig. 7 to illustrate the effects of fluorine and water on cationic diffusivities in silicate melts. For the discussion of compensation we will refer to the lines labelled 1 through 5 and the data for F-O interdiffusion (open circles) and $\mathrm{H}_{2} \mathrm{O}$ chemical diffusion (solid circles). The inset and cationic diffusivity data in Fig. 7 will be discussed in the next section.

WINCHELL and NORMAN (1969) first showed a positive correlation between the frequency factors and activation energies of various cationic diffusivities in $\mathrm{Ca}_{40} \mathrm{Al}_{20} \mathrm{Si}_{40}$ melt (Fig. 7; line 2). From this correlation they defined a compensation "law" for silicate melt diffusivities which WINCHELL (1969) extended to other synthetic melt compositions. HOFMANN (1980) proposed an equivalent relationship for basalt and obsidian melts incorporating cationic and oxygen diffusivity data (line 4). HART (1981) distinguished two separate compensation laws, one for basalt melts (line 1), and one for obsidian melts (line 5), and finally, DunN (1982) proposed a compensation law for various synthetic silicate melts based on oxygen diffusivities (line 3). An important physical implication of compensation in silicate liquids is that all melt diffusivities converge at a unique temperature ( $T$ critical or $T c$ ), which may or may not be attained in nature. The implications of such behavior are discussed at length by HART (1981). Also, compensation plots provide a test of the consistency of diffusion data for a given melt composition. Fig. 7 is a compensation plot which includes our results for the chemical diffusion of fluorine and the results of KARSTEN et al. (1982) and DELANEY and KARSTEN (1981) for the chemical diffusion of water. It is clear in Fig. 7 that our fluorine data may be included equally well within any of the compensation law relationships except the obsidian curve of HART (1981). The same conclusion is evident for the $\mathrm{H}_{2} \mathrm{O}$ data. The agreement of the fluorine and water data with the compensation laws for depolymerized melts (lines 1 to 4 ) suggests that water and fluorine depolymerize obsidian and jadeite melts, respectively.

\section{Effect of water and fuorine on cationic diffusivities}

Figure 7 emphasizes a second and very important aspect of fluorine and water in silicate melts. Included in Fig. 7 are the data available on the effect: of (1) water on $\mathrm{Ca}, \mathrm{Na}$ and $\mathrm{Cs}$ diffusivities (WATSON, 1981) and the influence of (2) fluorine on $\mathrm{Ca}$ and $\mathrm{Fe}$ diffusivities (JoHNSTON et al., 1974). The influences of water and fluorine on cationic diffusivities are large. All cationic diffusivities investigated increase when either water or fluorine is added to the silicate 


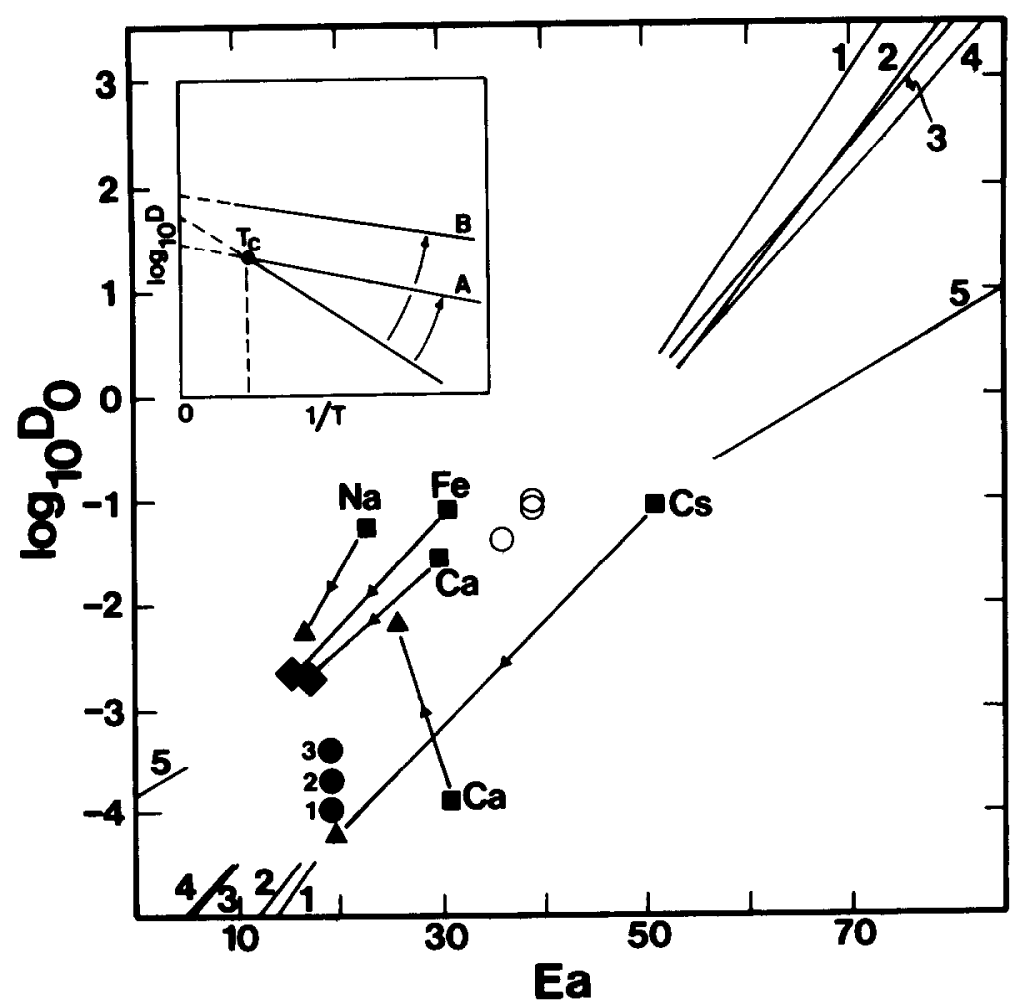

FIG. 7. Compensation plot for silicate melt diffusivities showing 1) data for $\mathrm{H}_{2} \mathrm{O}$ chemical diffusion at 1,2 and 3 wt\% water (KARSTEN et al., 1982; solid circles) and F-O interdiffusion (this study; open circles) 2) compensation laws (solid lines, see text for references to numbers) 3) cationic diffusivities in dry, Ffree melts (squares); in hydrous melts (triangles); and in F-bearing melts (diamonds) (inset: the behavior of cationic diffusivity-temperature relationships with the addition of fluorine or water, see text for discussion of cases $A$ and $B$ ).

melt. In most cases, the increased diffusivity yields a lower activation energy and frequency factor $\left(\log _{10} D_{0}\right)$ and, in these cases, the Arrhenius relationship for cationic diffusivity describes a line which rotates about a critical temperature, $T c$ (Fig. 7, inset, case A). This behavior produces a trend on the compensation plot which is sub-parallel to the various compensation relationships. In Fig. 7, several cationic diffusivities are affected in this manner (e.g. increases in $\mathrm{Ca}$ and $\mathrm{Fe}$ diffusivities in fluorine-bearing melt and increases in $\mathrm{Cs}$ and $\mathrm{Na}$ diffusivities in hydrous melts). The behavior of $\mathrm{Ca}$ in hydrous melt is somewhat anomalous because the increase in $\mathrm{Ca}$ diffusivity takes the form of a bulk translation of the Arrhenius line (Fig. 7, inset, case B) yielding a lower activation energy but a higher frequency factor. However, th trends of $\mathrm{Ca}$ and $\mathrm{H}_{2} \mathrm{O}$ diffusivity with increasing water content are similar (Fig. 7). Regardless of the mechanisms responsible, increased diffusivity of cations with addition of fluorine or water to silicate melts, has significant implications for the roles of $\mathrm{F}$ and $\mathrm{H}_{2} \mathrm{O}$ in establishing chemical equilibrium during igneous processes.

\section{Geologic applications}

Jadeite melt has a highly polymerized structure similar to natural melts whose compositions are approximated by the system nepheline-kalsilite-silica
(SEIFERT et al., 1982). Relatively dry, rhyolitic, trachytic and phonolitic melts often contain up to $1 \mathrm{wt} \%$ fluorine (CARMICHAEL et al., 1974; BAILEY, 1977; CHRISTIANSEN et al., 1983). The present diffusion data provide information on a very important aspect of the petrogenesis of relatively dry, felsic melts. It has been observed experimentally that dry or waterundersaturated melts of rhyolitic and feldspathic composition have extremely slow equilibration rates due to low diffusivities in the melts (SCHAIRER, 1950; PIWINSKII, 1967; WHITNEY, 1975). JOHANNES (1978, 1980) has proposed that even water-saturated granitic melts have equilibration rates, below $700^{\circ} \mathrm{C}$, which are low enough to yield metastable melt compositions in nature. Considering the dramatic effect of fluorine on diffusivities in silicate melts, the presence of fluorine in dry rhyolitic melts could be a crucial factor in determining the rate of establishment and the physical extent of chemical equilibrium during anatexis in the lower crust.

Fluorine increases cationic diffusivities in depolymerized melts (such as $\mathrm{Ca}_{40} \mathrm{Al}_{20} \mathrm{Si}_{40}$; JOHNSTON et al., 1974). Therefore, perhaps fluorine is capable of increasing diffusivities in melts which are already depolymerized due to dissolved water. This potential additive effect of fluorine and water on the diffusivities of various cations in late-stage, water-saturated, granitic melts may yield exceptionally high melt diffusivities. 


\section{SUMMARY AND CONCLUSIONS}

The chemical diffusion of fluorine in a jadeite melt involves binary interdiffusion of fluorine and oxygen. This interdiffusion is concentration independent from 0 to 6 wt $\%$ fluorine. This contrasts with $\mathrm{Si}-\mathrm{Ge}$ and Al-Ga interdiffusion in jadeite melt. High temperature fluorine diffusion, both chemical and tracer, is equal to or greater than both cationic and oxygen diffusion in fluorine-free melts. Chemical diffusivity of fluorine in jadeite melt is similar in magnitude to the chemical diffusion of water in obsidian melts. However, chemical diffusion of fluorine has an Arrhenius activation energy of 36-39 kcal/mole compared with $19 \mathrm{kcal} /$ mole for chemical diffusion of water in obsidian melts and for tracer diffusion of fluorine in $\mathrm{Ca}_{40} \mathrm{Al}_{20} \mathrm{Si}_{40}$ melt. The results fit several of the compensation "laws" which have been proposed for cationic and anionic diffusivities in depolymerized silicate melts. A significant effect of fluorine on melt diffusivities is that cationic diffusivities are enhanced by the addition of fluorine to silicate melts. This behavior is also observed when water is added to silicate melts. The effect of fluorine on melt diffusivities may be a significant factor in the chemical equilibration of dry, igncous melts.

Acknowledgements-We wish to thank S. Launspach for assistance with probe operation and data reduction and $\mathrm{F}$. Dimitrov for help with the drafting. Scarfe acknowledges support of NSERC grant A 8394 and Dingwell acknowledges support from a 1967 NSERC science scholarship. The microprobe facilities at $\mathrm{U}$. of $\mathrm{A}$. are operated with funds from NSERC grant A 4254 awarded to D. G. W. Smith. M. Brearley, J. E. Dickinson, B. J. Giletti, T. Dunn and an anonymous reviewer are thanked for critical reviews. Experimental Petrology Laboratory publication 87

\section{REFERENCES}

ARZI A. A. (1978) Fusion kinetics, water pressure, water diffusion and electrical conductivity in melting rock, interrelated. J. Petrol. 19, 153-169.

BAILEY J. C. (1977) Fluorine in granitic rocks and melts: a review. Chem. Geol. 19, 1-42.

BURNHAM C. W. (1979) The importance of volatile constituents. In The Evolution of the Igneous Rocks (ed. H. S. YODER), pp. 439-482. Princeton University Press.

Burt D. M., Sheridan M. F., BikUN J. V. and ChrisTIANSEN E. H. (1982) Topaz rhyolites-Distribution, origin and significance for exploration. Econ. Geol. 77, $1818-1836$

Carmichael I. S. E., Turner F. J. and Verhoogen J (1974) Igneous Petrology. McGraw Hill, 739 p.

Christiansen E. H., Burt D. M., Sheridan M. F. and WILSON R. T. (1983) The petrogenesis of topaz rhyolites from the western United States. Contrib. Mineral. Petrol. $83,16-30$

CLARK S. P. (1959) Effect of pressure on the melting points of eight alkali halides. J. Phys. Chem. 31, 1526-1531

COOPER A. R. (1968) The use and limitation of the concept of an effective binary diffusion coefficient for multicomponent diffusion. In Mass Transport in Oxides (eds. J. B. WACHTMAN JR. and A. D. Franklin). Natl. Bur. Stds. Spec. Publ. 296, pp. 79-84.

Crank J. (1975) The Mathematics of Diffusion, 2nd ed., Oxford University Press, $414 \mathrm{p}$
DELANEY J. R. and KARSTEN J. L. (1981) Ion microprobe studies of water in silicate melts: concentration-dependent diffusion in obsidian. Earth Plant. Sci. Lett 52. 19!. 202

Dingwell D. B., SCARFF (. M. and Cronin D. I. (1984) The effect of fluorine on viscosities in $\mathrm{Na}_{2} \mathrm{O}-\mathrm{Al}_{2} \mathrm{O}_{3}-\mathrm{SiO}_{2}$ Amer. Mineral. (in press).

DUNN T. (1982) Oxygen diffusion in three silicate melts along the join diopside-anorthite. Geochim. Cosmochim. Acta 46, 2293-2299.

DUNN T. (1983) Oxygen chemical diffusion in three basaltic liquids at elevated temperatures and pressures. Geochim. Cosmochim. Acta 47, 1923-1930.

FrIEDMAN I. and LONG W. (1976) Hydration rate of obsidian. Science 191, 347-352.

HARDS N. (1978) Distribution of elements between the fluid phase and silicate melt phase of granites and nepheline syenites. NERC Prog. Exptl. Pet. IV, 88-90.

HARRIS N. B. W. and MarRINer G. F, (1980) Geochemistry and petrogenesis of a peralkaline granite complex from the Midian Mountains, Saudi Arahia. Lithos 13, 325337.

HaRT S. R. (1981) Diffusion compensation in natural silicates. Geochim. Cosmochim. Acta 45, 279-291

Henderson J., YANG I.. and DerGe G. (1961) Selfdiffusion of aluminum in $\mathrm{CaO}-\mathrm{SiO}_{2}-\mathrm{Al}_{2} \mathrm{O}_{3}$ melts. Trans. AIME 221, 56-60.

HOFMANN A. W. (1980) Diffusion in natural silicate melts a critical review. In Physics of Magmatic Processes (ed. R. B. Hargraves), Chap. 9, pp. 385-415. Princeton University Press.

Jambon A., Carron J P. and Delbove F. (1978) Donnees preliminaires sur la diffusion dans les magmas hydrates: le cesium dans une liquide granitique a $3 \mathrm{~kb} . C . R . A c a d$. Sci. Ser. D. 287, 403-406.

JOHANNES W. (1978) Melting of plagioclase in the system $\mathrm{Ab}-\mathrm{An}-\mathrm{H}_{2} \mathrm{O}$ and $\mathrm{Qz}-\mathrm{Ab}-\mathrm{An}-\mathrm{H}_{2} \mathrm{O}$ and $\mathrm{P}\left(\mathrm{H}_{2} \mathrm{O}\right)=5$ kbars. an equilibrium problem. Contrib. Mineral. Petrol. 66, 295-303

JOHANNES W. (1980) Metastable melting in the granite system Qz-Ab-An- $\mathrm{H}_{2} \mathrm{O}$. Contrib. Mineral. Petrol. 72, 7380

JOHNSTON R. F., STARK R. A. and TAYLOR J. (1974) Diffusion in liquid slags. Ironmaking Steelmaking 1, 220227.

Karsten J. L., Holloway J. R. and Delaney J. R. (1982) In microprobe studies of water in silicate melts: temperature-dependent water diffusion in obsidian. Earth Planet. Sci. Lett. 59, 420-428.

KoROS P. J, and KING T. B. (1962) The self-diffusion of oxygen in a lime-silica-alumina slag. Trans. $4 I M E \mathbf{2 2 4}$, 299-306.

KUSHIRO I. (1976) Changes in viscosity and structure of melt of $\mathrm{NaAlSi}_{2} \mathrm{O}_{6}$ composition at high pressures. $I \mathrm{GeO}-$ phys. Res. 81, 6347-6350.

KUSHIRO 1. (1983) Effect of pressure on the diffusivity of network-forming cations in melts of jadeitic compositions. Geochim. Cosmochim. Acta 47, 1415-1422.

MANNING D. A. C., HaMILTON D. L., HeNDERSON C. M. B. and DEMPSEY M. J. (1980) The probable occurrence of interstitial $\mathrm{Al}$ in hydrous $\mathrm{F}$-bearing and $\mathrm{F}$ free aluminosilicate melts. Contrib. Mineral. Petrol. 75, $257-262$.

OISHI Y., TERAI R. and UEDa H. (1975) Oxygen diffusion in liquid silicates and relation to their viscosity. In Mass Transport Phenomena in Ceramics (eds. A. R. COOPER and A. R. HeUER) pp. 297-310. Plenum Press.

PIWINSkIl A. J. (1967) The attainment of equilibrium in hydrothermal experiments with granitic rocks. Earth Planet. Sci. Lett. 2, 161-162.

SCHAIRER J. (1950) The alkali-feldspar join in the system $\mathrm{NaAlSiO}_{4}$-KAlSiO $4-\mathrm{SiO}_{2}$. J. Geol. 58, 512-517.

SEIFERT F.. MYSEN B. O. and VIRGO D. (1982) Three 
dimensional network structure of quenched melts (glass) in the systems $\mathrm{SiO}_{2}-\mathrm{NaAlO}_{2}, \mathrm{SiO}_{2}-\mathrm{CaAl}_{2} \mathrm{O}_{4}$ and $\mathrm{SiO}_{2}$ $\mathrm{MgAl}_{2} \mathrm{O}_{4}$. Amer. Mineral. 67, 696-717.

ShARMA S. K., VIRGo D. and MYSEN B. O. (1979) Raman study of the coordination of aluminum in jadeite melts as a function of pressure. Amer. Mineral. 64, 779-787.

SHAw H. R. (1974) Diffusion of $\mathrm{H}_{2} \mathrm{O}$ in granitic liquids. Part I. Experimental Data; Part II. Mass transfer in magma chambers. In Carnegie Inst. Washington Publ. 634 (eds. A. W. HofmanN, B. J. GiletTI, H. S. YOder and R. A. YUND) (Geochemical Transport and Kinetics Conference, 1973), 139-170.

SHIMIZU N. and KUSHIRo I. (1984) Diffusivity of oxygen in jadeite and diopside melts at high pressures. Geochim. Cosmochim. Acta 48, 1295-1304.

SMITH D. G. W. and Gold C. (1979) EDATA2: a FORTRAN IV computer program for processing wavelengthand/or energy-dispersive electron microprobe analyses. In Proc. Ann. Conf. Microbeam Anal. Soc., 1979, 14th. 273278.

Smith J. V., Delaney J. S., Hervig R. L. and Dawson J. B. (1981) Storage of $\mathrm{F}$ and $\mathrm{Cl}$ in the upper mantle: geochemical implications. Lithos 14, 133-147.

Towers H. and CIIIPMAN J. (1957) Diffusion of calcium and silicon in a lime-alumina silica slag. Trans. AIME 209, 769-773.
Valley J. W., Petersen E. U., Essene E. J. and Bowman J. R. (1982) Fluorphlogopite and fluortremolite in Adirondack marbles and calculated C-O-H-F fluid compositions. Amer. Mineral. 67, 545-557.

WATSON E. B. (1979) Calcium diffusion in a simple silicate melt to 30 kbar. Geochim. Cosmochim. Acta 43, 313322.

WATSON E. B. (1981) Diffusion in magmas at depth in the earth: the effects of pressure and dissolved water. Earth Planet. Sci. Lett. 52, 291-301.

WENDLANDT R. (1980) Oxygen diffusion in basalt and andesite melts. EOS 61, 1142.

WHITNEY J. A. (1975) The effects of pressure, temperature and $X\left(\mathrm{H}_{2} \mathrm{O}\right)$ on phase assemblage in four synthetic rock compositions. J. Geol. 83, 1-31.

WhITTAKer E. J. W. and MUNTUS R. (1970) Ionic radii for use in geochemistry. Geochim. Cosmochim. Acta 34, 945-956.

WINCHELL P. (1969) The compensation law for diffusion in silicates. High Temperature Science 1, 200-215.

WINCHELl P. and NoRMAN J. H. (1969) A study of the diffusion of radioactive nuclides in molten silicates at high temperatures. In High Temperature Technology. Third Int. Symp. Asilomar, 1967, 479-492. 